\title{
Cirrhotomimetic hepatocellular carcinoma: experience of a single institution and review of the literature
}

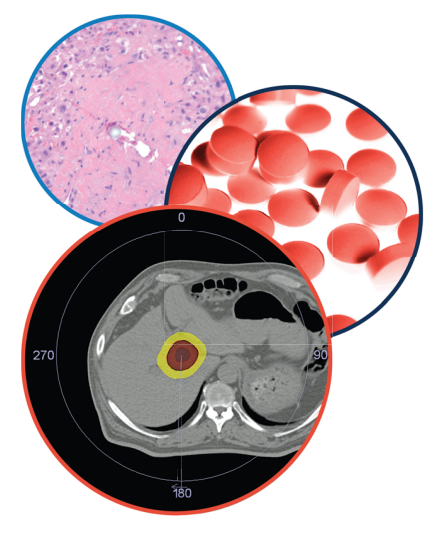

Hepatic Oncology

\author{
Meng-Jun Xiong1 (iD), Chirag R Patel ${ }^{1}$ (D), Upender Manne ${ }^{1,2}$ (i) \& Sameer Al Diffalha*,1,2 (iD) \\ ${ }^{1}$ Department of Pathology, University of Alabama at Birmingham, Birmingham, AL 35294, USA \\ ${ }^{2} \mathrm{O}^{\prime} \mathrm{Neal}$ Comprehensive Cancer Center, University of Alabama at Birmingham, Birmingham, AL 35294, USA \\ *Author for correspondence: saldiffalha@uabmc.edu
}

Cirrhotomimetic hepatocellular carcinoma is a recognized pattern exhibiting cirrhosis-like growth and a reputation for evading pretransplant detection. Five cases encountered from our institution were retrospectively reviewed. Clinicopathologic and literature reviews were performed. All five patients were male, aged 50-66. Diffuse, innumerable nodules were seen grossly, exhibiting predominantly well-to-moderate differentiation with pseudoglandular and trabecular patterns microscopically. By immunohistochemistry, the tumor was diffusely positive for Glypican-3, showed sinusoidal capillarization by CD34 and slightly increased MIB-1 proliferation index. At up to 3.25 years of follow-up, our cohort of cirrhotomimetic hepatocellular carcinoma had no recurrence in $60 \%(3 / 5)$, solitary recurrence in $20 \%(1 / 5)$ and one patient had died of disease in $20 \%(1 / 5)$. Literature review suggests that these tumors recurred at a frequency of $50 \%$ (19 of 38 patients).

First draft submitted: 4 May 2020; Accepted for publication: 13 July 2020; Published online: 21 August 2020

Keywords: cirrhotic like $\bullet$ cirrhotomimetic $\bullet$ cirrhotomimetic hepatocellular carcinoma $\bullet$ diffuse type hepatocellular carcinoma • hepatocellular carcinoma

Hepatocellular carcinoma (HCC) is the 5th leading cause of cancer deaths for men and the 7th leading cause of death for women, according to 2019 American Cancer Society statistics [1]. Chronic liver disease and cirrhosis are risk factors for the development of HCC. According to the 2005 practice guidelines of the American Association for the Study of Liver Diseases, over $80 \%$ of patients diagnosed with HCC have underlying cirrhosis [2]. One of four macroscopic patterns recognized in the 5th edition of the WHO Classification of Tumors (Digestive System Tumors) is the diffuse or cirrhotomimetic pattern, in which innumerable tumor nodules resembling cirrhotic nodules are evident, and present anecdotally as a clinical and radiographic occult tumor [3]. Cirrhotomimetic HCCs (CM-HCCs) pose particular clinical challenges, since they escape early radiographic detection. Current American Association for the Study of Liver Diseases surveillance guidelines (2018 Practice Guidance) for HCC recommend surveillance ultrasound with or without serum alpha-fetoprotein (sAFP) evaluation every 6 months. A 'positive' result on surveillance is defined as an ultrasound detected lesion $\geq 10 \mathrm{~mm}$ or, alternatively, a $>20 \mathrm{ng} / \mathrm{ml}$ elevation in sAFP. A positive result is further diagnostically evaluated by computed tomography (CT) (with arterial, venous and delayed phases) and/or multiplanar multisequence MRI according to institution-specific protocol, and by biopsy, if indicated [4]. If they meet the Milan criteria, patients diagnosed with HCC are prioritized for orthotopic liver transplant, which show favorable outcome with transplant. Given that CM-HCCs produce numerous (from dozens to hundreds) nodules throughout the liver, the overall tumor burden would have exceeded acceptable criteria for transplant; in other words, these tumors retrospectively would not have met criteria for transplant. Moreover, the prognosis for patients with CM-HCC, given its rarity, is unclear. Our aim was to review our institution's experience of CM-HCC as well as review existing literature regarding pre-operative and post-operative clinicopathologic, imaging and follow-up data to assess overall outcome and histologic features that could have led to a poor outcome.

Future Medicine 


\section{Materials \& methods}

We diagnosed a case of CM-HCC in our routine gastrointestinal pathology service, and given that this is a rare tumor, we decided to perform a database search to see if there were prior cases to compare. This yielded an additional four cases. All of the cases were diagnosed from 2015 to 2019. To conduct this study, we obtained approval from the Institutional Review Board of the University of Alabama at Birmingham.

All data elements were gathered retrospectively. Pretransplant and clinical characteristics were collected from the University of Alabama at Birmingham electronic medical records to include age, sex, ethnicity, underlying liver disease, treatment history, pre-operative sAFP, model for end-stage liver disease score, pre-operative imaging characteristics, recurrence-free survival, presence or absence of metastatic disease and length of follow-up.

Hematoxylin and eosin (H\&E), immunohistochemical (IHC)-stained and special stained slides that were available for all cases, were reviewed by two gastrointestinal pathologists (S Al Diffalha and C Patel) and by a gastrointestinal pathology fellow (M Xiong). All patients underwent a native total hepatectomy operation, and the sections were submitted for pathologic evaluation, following institution-specific sampling protocols for random and/or queried nodules. Gross photographs, if available, were retrieved. Pathologic characteristics were collected from original reports or extrapolated from the available slides, including confirmation of cirrhosis, lobes or segments involved by tumor, estimated tumor burden volume (if reported), size range of nodules, predominant histologic pattern, tumor grade, pathologic stage (according to the American Joint Committee on Cancer, AJCC, 8th edition) and interpretations of IHC and special stains. Since these data were retrospectively gathered, individual staining profiling varied slightly, but cumulatively included Glypican-3 (1G12; predilute; Leica; IL, USA), CD34 (QBEnd/10; predilute; Leica), MIB-1 proliferation index (rabbit monoclonal; Ventana; predilute; Oro Valley, AZ 85755), CK7 (rabbit monoclonal; predilute; Ventana; AZ USA), CK19 (b170; predilute; Leica), alpha-fetoprotein (AFP) (c3; predilute; Ventana), HepPar-1 (och1E5; predilute; Leica) and special stain for reticulin (chemical reaction; Roche; AZ, USA).

\section{Results \\ Clinical \& imaging characteristics}

Our cohort comprised five male patients, ranging 50-66 years old, with a mean age of 58. Four of the five patients were non-Hispanic Caucasians, and one was African-American. All had cirrhosis with chronic liver disease attributable to various etiologies in descending order (with overlap): hepatitis $\mathrm{C}$ virus (three patients), nonalcoholic steatohepatitis (NASH) (two patients), alcoholic hepatitis (ETOH) (two patients) and hepatitis B virus (one patient). All of the patients had a multiplanar multisequence MRI during liver transplant evaluation. Additionally, $80 \%$ of the patients also had CT abdomen imaging with arterial, venous and delayed phases acquired. Imaging protocols were strictly followed and time between exam intervals averaged 3 months (Supplementary Table 1 for additional imaging characteristics). One patient had a biopsy proven HCC dominant nodule that was $4.4 \mathrm{~cm}$ by radiographic imaging and treated by transarterial chemoembolization (case 4; Table 1); a smaller suspicious nodule $(1.2 \mathrm{~cm}$ ) was evident on imaging. His sAFP level was modestly elevated at $232 \mathrm{ng} / \mathrm{ml}$. Two patients had indeterminate lesions or subtle mass enhancement on imaging with modest sAFP elevation (192 to $344 \mathrm{ng} / \mathrm{ml}$ and $93.5 \mathrm{ng} / \mathrm{ml}$ in case 3 and case 5, respectively; Table 1). The remaining two patients had no clinically detectable lesions by imaging, and their sAFP were in the normal range (cases 1 and 2; Table 1). Overall, the pretransplant sAFP for all patients ranged from 8.2 to $344 \mathrm{ng} / \mathrm{ml}$ at its peak, which is normal to slightly elevated. As previously stated, case 4 had a biopsy proven HCC, but his additional tumors were clinically occult. Case 1 had a prior liver biopsy showing steatohepatitis, but no evidence of neoplastic lesions 2 years prior to transplant. The remaining patients had no prior biopsy history. Reported pretransplant model for end-stage liver disease ranged from 7 to 29 at $\geq 3$ months and 24-41 a week before transplant. All of the patients met orthotopic liver transplantation criteria and underwent total hepatectomy.

\section{Gross \& microscopic characteristics}

Gross examination of the explanted livers showed a cirrhotic cut surface with innumerable nodules, at least 150 in submitted sections (case 2), and ranging from 0.2 to $1.7 \mathrm{~cm}$ in size. In all cases, both liver lobes were involved. Although some nodules appeared subtlety green or pale compared with the cirrhotic background, no distinct lesions were evident (Figure 1). Of note, case 4 had a known treated dominant nodule that was grossly identified and sampled. However, this case was included because, in addition to the dominant nodule, there were innumerable tumor nodules $(0.2$ to $1.3 \mathrm{~cm})$ that were detected on microscopic examination. A nodule-in-nodule formation in 
Table 1. Clinicopathologic characteristics of cirrhotomimetic-hepatocellular carcinoma cases.

\begin{tabular}{|c|c|c|c|c|c|}
\hline Parameters & Case 1 & Case 2 & Case 3 & Case 4 & Case 5 \\
\hline Age (years) & 50 & 58 & 56 & 60 & 66 \\
\hline Sex & Male & Male & Male & Male & Male \\
\hline Ethnicity & Caucasian & African-American & Caucasian & Caucasian & Caucasian \\
\hline Clinical history & NASH & HCV, HBV, ETOH & HCV, ETOH & $\mathrm{HCV}$ & NASH \\
\hline Pre-operative imaging ${ }^{\dagger}$ & No lesions & No lesions & Subtle mass-like area & $\begin{array}{l}\text { Largest nodules ( } 4.4 \text { and } \\
1.2 \mathrm{~cm} \text { ) detected by } \\
\text { imaging }\end{array}$ & $\begin{array}{l}\text { Multiple indeterminate } \\
\text { lesions with dominant } \\
\text { nodule }(2 \mathrm{~cm})\end{array}$ \\
\hline $\begin{array}{l}\text { Pre-operative serum AFP } \\
(\mathrm{ng} / \mathrm{ml}) ; \text { result; date of result }\end{array}$ & $\begin{array}{l}\text { 10.3; normal (1 month } \\
\text { prior) }\end{array}$ & 8.2; normal (1 year prior) & $\begin{array}{l}\text { 192; elevated ( } 1 \text { month } \\
\text { prior) } \\
\text { 344; elevated ( } 4 \text { months } \\
\text { prior) }\end{array}$ & $\begin{array}{l}\text { 232; elevated ( } 3 \text { months } \\
\text { prior) }\end{array}$ & $\begin{array}{l}\text { 93.5; elevated ( } 2 \text { months } \\
\text { prior) }\end{array}$ \\
\hline Biopsy history & $\begin{array}{l}\text { Biopsy } 2 \text { years prior with } \\
\text { steatohepatitis }\end{array}$ & None & None & $\begin{array}{l}\text { Biopsy proven } \\
\text { moderately- } \\
\text { differentiated HCC prior } \\
\text { to TACE }\end{array}$ & None \\
\hline Treatment history & None & None & None & $\begin{array}{l}\text { Only largest nodule } s / p \\
\text { TACE } / \text { XRT }\end{array}$ & None \\
\hline Pretransplant MELD Score & $\begin{array}{l}29 \text { ( } 3 \text { months prior) } \\
41 \text { ( } 1 \text { week prior) }\end{array}$ & 27 (1 year prior) & $\begin{array}{l}21 \text { ( } 4 \text { months prior) } \\
26 \text { ( } 2 \text { months prior) } \\
40 \text { ( } 1 \text { month prior) }\end{array}$ & $\begin{array}{l}7 \text { (4 months prior) } \\
7 \text { ( } 3 \text { months prior) }\end{array}$ & $\begin{array}{l}13 \text { ( } 9 \text { months prior) } \\
17 \text { ( } 1 \text { month prior) } \\
24 \text { ( } 1 \text { week prior) }\end{array}$ \\
\hline Follow-up period (years) & 1.3 & 2.0 & 3.25 & 1.4 & 1.3 \\
\hline Recurrence-free survival (years) & 1.3 & 2.0 & 1.7 & 0.7 & 1.3 \\
\hline Metastatic disease & No & No & $\begin{array}{l}\text { Yes } \\
\text { Solitary metastasis to } \\
\text { adrenal }\end{array}$ & $\begin{array}{l}\text { Yes } \\
\text { Metastasis to celiac } \\
\text { lymph node \& T2 \& T4 } \\
\text { bone (later by imaging } \\
\text { only) }\end{array}$ & No \\
\hline $\begin{array}{l}\text { Peri-operative outpatient } \\
\text { follow-up comments }\end{array}$ & $\begin{array}{l}\text { Karnofsky scale: } 90 \% \\
\text { ECOG Performance } \\
\text { Scale: } 0\end{array}$ & $\begin{array}{l}\text { Unchanged allograft } \\
\text { function } \\
\text { Compliance issues with } \\
\text { ETOH }\end{array}$ & $\begin{array}{l}\text { ECOG Performance } \\
\text { Scale: } 0 \\
\text { Clinically stable }\end{array}$ & $\begin{array}{l}\text { Stable graft function at } \\
\text { last visit } \\
\text { Hilar mass/metastasis } \\
\text { treated with XRT } \\
\text { (5 months postop) }\end{array}$ & $\begin{array}{l}\text { Unchanged allograft } \\
\text { function } \\
\text { Patient reports doing } \\
\text { well }\end{array}$ \\
\hline Alive at last follow-up & Yes & Yes & Yes & No & Yes \\
\hline Background liver & Cirrhosis/ESLD & Cirrhosis/ESLD & Cirrhosis/ESLD & Cirrhosis/ESLD & Cirrhosis/ESLD \\
\hline Lobes involved by $\mathrm{CM}-\mathrm{HCC}$ & Bilateral & Bilateral & Bilateral & Bilateral & Bilateral \\
\hline $\begin{array}{l}\text { Estimated volume of tumor } \\
\text { burden }(\%) \text {; descriptive } n \text { of } \\
\text { nodules }\end{array}$ & 75; numerous nodules & $\begin{array}{l}25-30 \text {; innumerable (at } \\
\text { least } 150 \text { in submitted } \\
\text { sections) }\end{array}$ & 70; innumerable & Unknown; innumerable & Unknown; innumerable \\
\hline Size range $(\mathrm{cm})$ & $1.0-1.7$ & up to 1.3 & $0.3-1.0$ & $\begin{array}{l}0.2-1.3 \text {; dominant } \\
\text { nodule is } 5.2\end{array}$ & $0.6-1.4$ \\
\hline Predominant histologic pattern & $\begin{array}{l}\text { Pseudoglandular and } \\
\text { focal steatotic changes }\end{array}$ & Pseudoglandular & $\begin{array}{l}\text { Pseudoglandular and } \\
\text { focal steatotic changes }\end{array}$ & Pseudoglandular & Pseudoglandular \\
\hline Histologic grade & G1 & G1-G2 & G1-G2 & G3 & G2 \\
\hline $\begin{array}{l}\text { Microscopic/small venous } \\
\text { invasion }\end{array}$ & No & Yes & No & Yes & No \\
\hline $\begin{array}{l}\text { Macroscopic/large venous } \\
\text { invasion }\end{array}$ & No & No & No & No & No \\
\hline $\begin{array}{l}\text { Pathologic stage (AJCC 8th } \\
\text { edition) }\end{array}$ & (m)pT2 pN0 & (m)pT2 pNX & (m)pT2 pNo & $y(m) p T 3 a p N 1$ & (m)pT2 pNX \\
\hline \multicolumn{6}{|c|}{$\begin{array}{l}\text { †For detailed imaging, see Supplementary Table } 4 . \\
\text { AJCC: American Joint Committee on Cancer; CM-HCC: Cirrhotomimetic HCC; d/t: Due to; ECOG: Eastern Cooperative Oncology Group Performance Scale; ESLD: End-stage liver disease; } \\
\text { ETOH: Alcohol hepatitis; HBV: Hepatitis B virus; HCC: Hepatocellular carcinoma; HCV: Hepatitis C virus; MELD: Model for end-stage liver disease; NASH: Nonalcoholic steatohepatitis; } \\
\text { s/p: Status post; TACE: Transarterial chemoembolization; XRT: Radiotherapy. }\end{array}$} \\
\hline
\end{tabular}

which nodules adhere to each other and coalesce to form a larger nodule is described by WHO [3] as a pattern of HCC growth; it has also been described for CM-HCCs [5].

The tumors exhibited classical hepatocellular morphology with predominantly trabecular and pseudoglandular growth patterns and well-to-moderate histologic differentiation. Focal steatosis was seen in two patients, one who had cirrhosis due to NASH. Feathery degeneration and cholestasis were seen, corroborating pale to green areas seen 


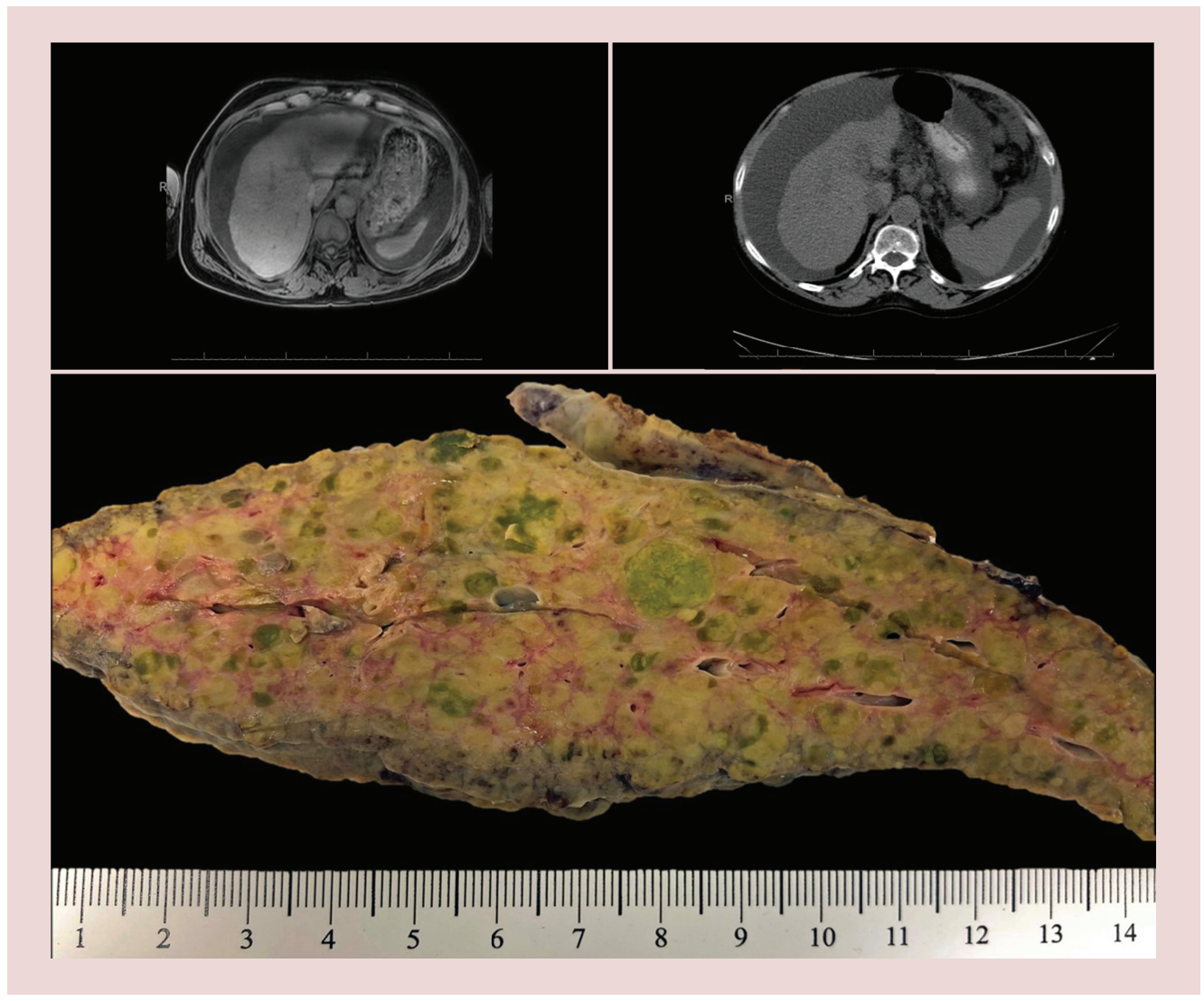

Figure 1. Case 2: magnetic resonance imaging without contrast with cirrhosis only (top left); subsequent computed tomography abdomen and pelvis without contrast with cirrhosis only (top right). Imaging limited due to lack of contrast due to patient glomerular filtration rate and concurrent end-stage kidney disease. Gross appearance: note the diffuse involvement of the liver parenchyma by innumerable pale, green, cholestatic sub-centimeter nodules that were found to harbor hepatocellular carcinoma at microscopic examination. The pale and cholestatic appearance of these nodules is a subtle clue on macroscopic examination for targeted sampling (bottom center).

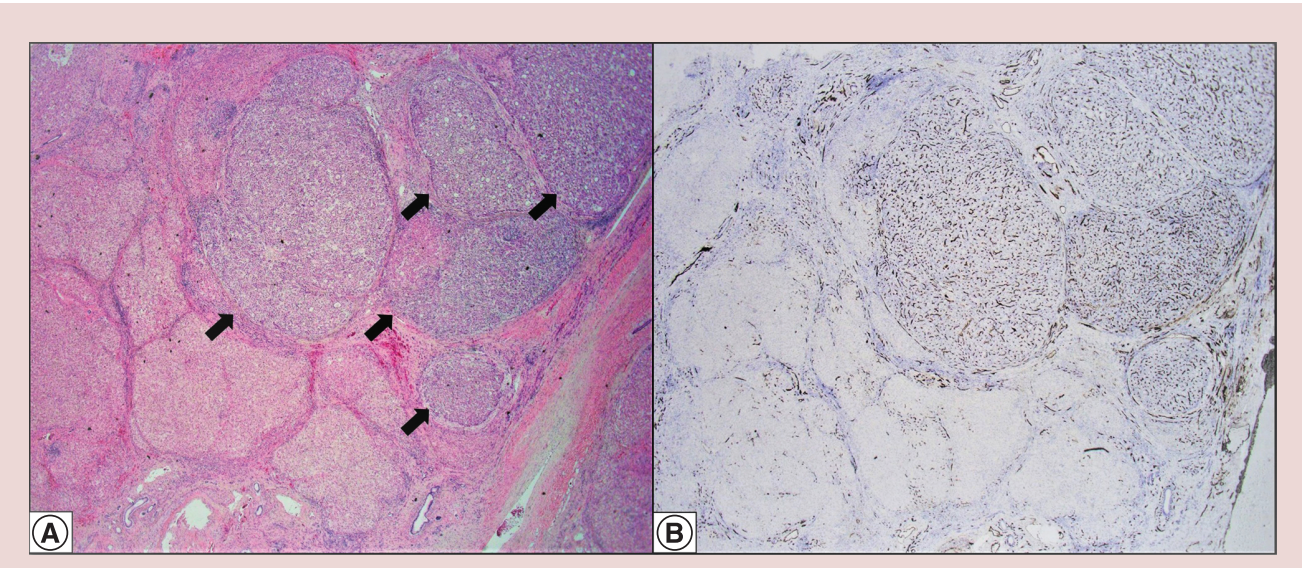

Figure 2. Microscopic features. Tumor nodules in a background of cirrhosis (arrows) (hematoxylin and eosin at $20 \times$ original magnification) (A). Sinusoidal capillarization pattern by CD34 (20x original magnification) (B).

grossly (Figures 2A \& 3B). Microscopic small venous invasion was present in two of five cases, but none showed large venous invasion (Figure $3 \mathrm{~A}$ ). IHC and special stain work-up varied between cases and are fully reported in 


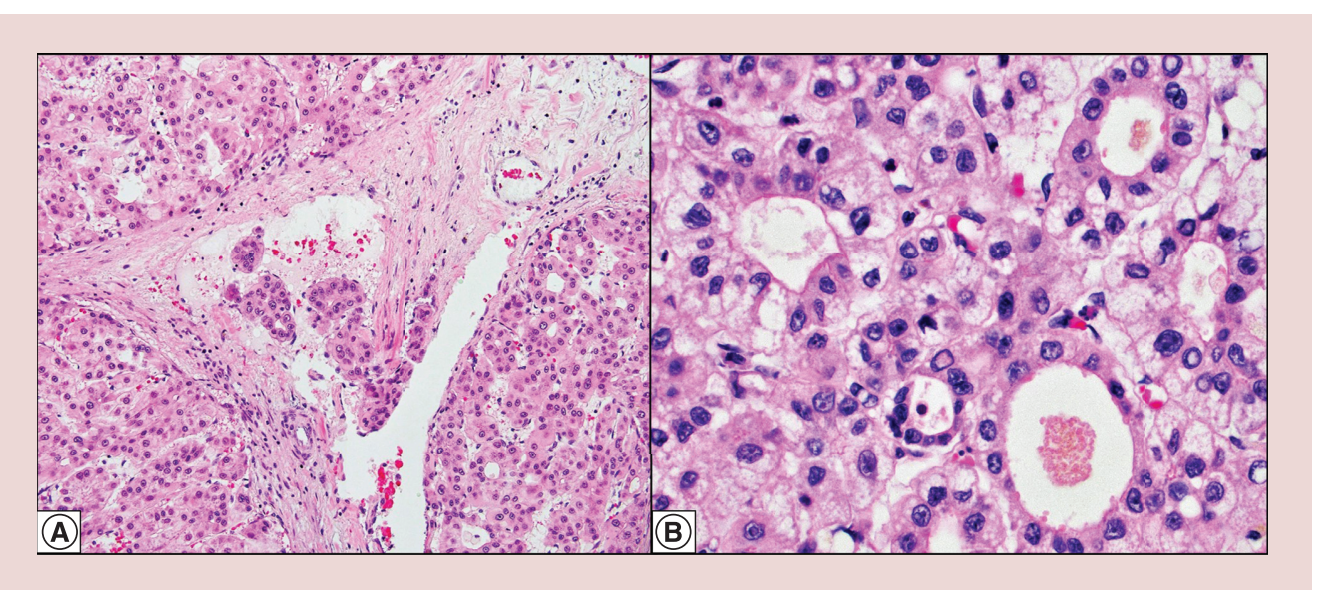

Figure 3. Microscopic venous invasion. There is tumor infiltration into small venous vasculature (hematoxylin and eosin at $200 \times$ original magnification) (A). Cirrhotomimetic hepatocellular carcinoma shows predominant pseudoglandular and trabecular histological growth patterns (hematoxylin and eosin at $400 \times$ original magnification) (B).

Table 3. In three cases where these stains were performed, all showed thickened plates in the tumor by reticulin special stain and glypican-3 expression, confirming HCC. The Glypican-3 was patchy in a well-differentiated example (case 1), and diffusely positive in two well-to-moderate differentiated examples (cases 2 and 3). Sinusoidal capillarization pattern by CD34 highlights the tumor nodules (Figure 2B). In case 2, AFP, CK7 and CK19 were negative in the tumor. In an attempt to assess proliferative rate objectively, a MIB- 1 proliferative index of $15 \%$ was calculated based on 88 positive tumor cells out of 588 cells manually counted on a camera-captured printed image. This supports our impression of a low proliferation rate (Figure 4D, case 2).

\section{Clinical outcomes}

As shown in Table 1, all patients had proven cirrhosis, related to various etiologies including hepatitis $\mathrm{C}$ virus, $\mathrm{NASH}$, hepatitis B virus and ETOH. For all cases, follow-up data were available, ranging from 1.3 to 3.25 years. Three patients remained recurrence-free at 1.3 to 2.0 years of follow-up. One patient developed a solitary metastasis to the adrenal gland at 1.7 years of follow-up (case 3; Table 1). All but one case was pathologically staged as (m)pT2 based on the presence of multiple small tumors, none greater than $5 \mathrm{~cm}$, according to the 8th edition of AJCC Staging Manual. The exception was case 4, who had a prior treated HCC that was microscopically confirmed as a $5.2 \mathrm{~cm}$ (by pathologic size, correlating to the radiologic $4.4 \mathrm{~cm}$ nodule), predominantly viable $(\sim 90 \%)$ tumor nodule. At pathologic diagnosis, in addition to the known mass, there were innumerable clinically occult small cirrhotic-like tumor nodules and a celiac lymph node metastasis.

The only patient to be staged as $\mathrm{y}(\mathrm{m}) \mathrm{pT} 3 \mathrm{a} \mathrm{pN} 1$, he subsequently developed additional metastases to bone and died of complications related to his disease at 1.4 years of follow-up. The outcome for this patient was likely driven by the poor histologic differentiation of the tumor [3,6]. Aside from objective outcome measures such as metastasis, recurrence and death, we also attempted to assess peri-operative outcomes from clinical notes by scoring softer (more subjective) outcome data such as Eastern Cooperative Oncology Group Performance Scale, Karnofsky Scale and reported graft function at last outpatient visit. Clinicopathologic characteristics are summarized in Table 1.

\section{Discussion}

CM-HCC, also known as cirrhotic-like HCC, diffuse type or confluent multinodular type, has a unique macroscopic appearance of multinodular to innumerable permeating tumor nodules that resemble cirrhosis. Classically, these tumors have a 'shock-factor' reputation for microscopic excessive tumor burden that evades clinical, radiographic and gross examination detection. This is explainable because there is a significantly decreased sensitivity for detecting lesions $\leq 20 \mathrm{~mm}$, approximately $48-57 \%$ compared with $83-100 \%$ for lesions $\geq 20 \mathrm{~mm} \mathrm{[7] \text {. }}$

Since these patients have been inadvertently transplanted, the real question becomes, 'does the excessive tumor burden portend poor outcome?' To answer this question requires an understanding of context in liver transplantation. The Milan criteria, developed by Mazzaferro [8] in 1996, are used in pretransplant staging and practice 


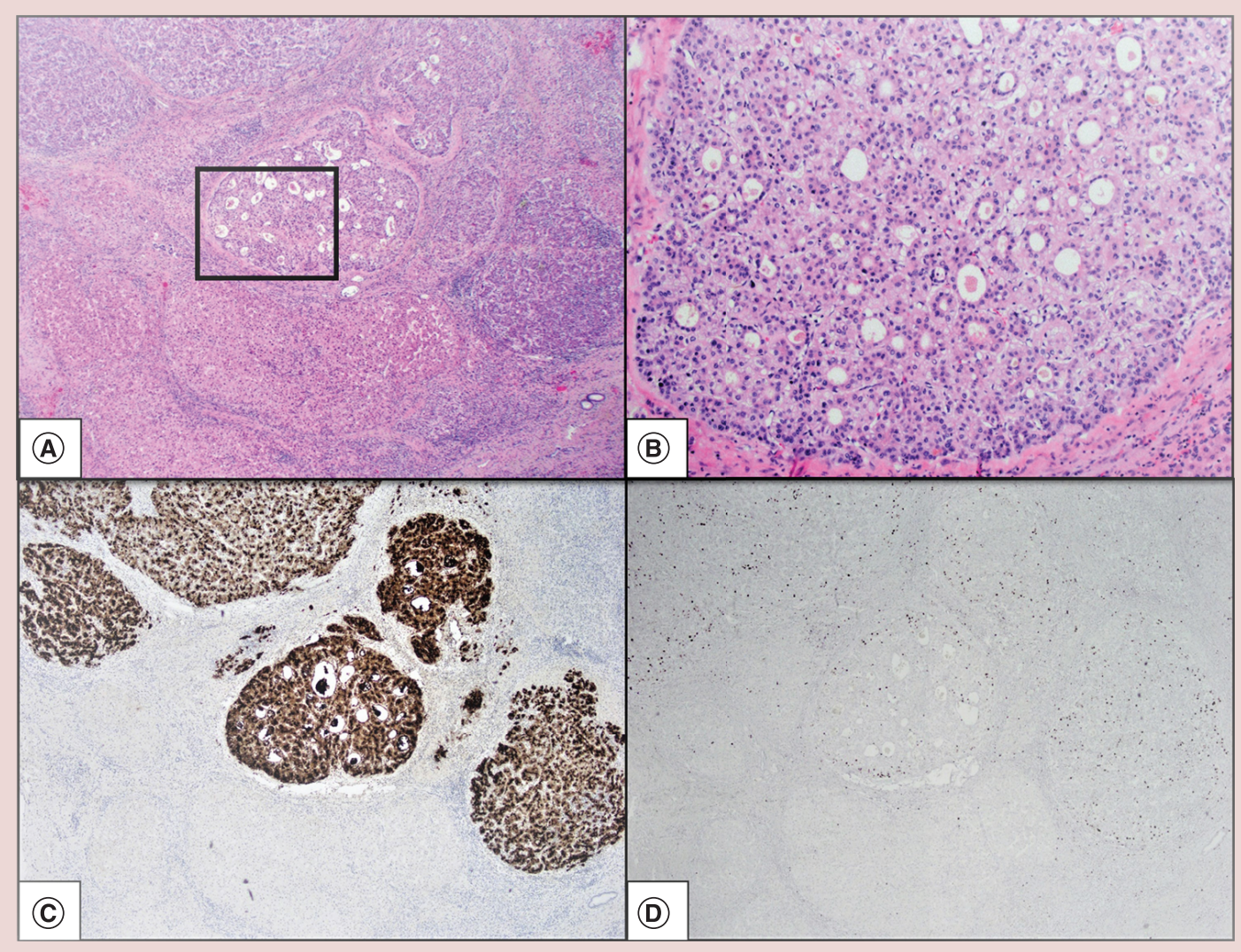

Figure 4. Mircroscopic Features. Hematoxylin and eosin at $20 \times$ original magnification (A). Hematoxylin and eosin at $100 \times$ original magnification (at box inset from A) (B). Glypican-3 highlights the small size and multiplicity of the tumors (20× original magnification) (C). Low MIB-1 proliferation index (20x original magnification) (D).

guidelines for the selection of patients who would have an optimal 5-year overall survival rate after liver transplantation for HCC compared with those patients who are transplanted for other reasons. The selection criteria allows for one lesion up to $5 \mathrm{~cm}$ in size, or up to three separate lesions (none over $3 \mathrm{~cm}$ ) provided that there is no vascular invasion or extrahepatic disease [8]. Other prospective 'expanded' selection criteria such as University of California San Francisco criteria have been considered, which would capture 'Milan-out' patients who have a solitary tumor $\leq 6.5 \mathrm{~cm}$ or not more than three tumors, with the largest not exceeding $4.5 \mathrm{~cm}$. However, these expanded criteria are not currently recommended outside of research purposes by practice guidelines [9]. CM-HCC is an exception to Milan and other proposed criteria. These patients would have been 'Milan-out', as microscopic examination would yield innumerable nodules, exceeding the upper limits for size and number. Yet, liver transplant may still offer the best outcome, since it resolves both the background at-risk cirrhotic liver and removes all the tumor tissue. However, the overwhelming tumor burden invites suspicion as to whether the tumor is likely to reoccur and portend a poor outcome.

The CM-HCC phenotype has been variously described in literature, but there has been evolution in terminology, study methods and treatment (e.g., partial vs total hepatectomy). Earlier macroscopic classifications of CM-HCC were primarily derived from descriptive autopsy studies by Eggel [10] and Yuki [11] who categorized these tumors as 'diffuse type' and 'contiguous multinodular type (Type 3)', respectively. Clinicopathologic characteristics from these studies are difficult to compare side to side, since these data were derived primarily from autopsies. A Japanese study [12] categorized CM-HCC as 'confluent multinodular-type', but these patients received partial hepatectomy and cirrhosis was present in only 24 of the 40 patients in the confluent multinodular-type group. In Asian countries, cadaveric liver donation is less common for possible cultural and/or religious reasons [9]. Since almost all of the patients had bi-lobar diffuse disease, removing only a partial hepatectomy may account for the high rate of intrahepatic metastasis seen in the Japanese study $(\sim 60 \%)[12]$. 


\begin{tabular}{|c|c|c|c|c|c|c|c|c|c|c|}
\hline Study (year) & $\mathrm{n}$ & Procedure & Imaging & $\begin{array}{l}\text { sAFP } \\
(\mathrm{ng} / \mathrm{ml})\end{array}$ & Background & $\begin{array}{l}\text { Predominant } \\
\text { pathologic growth } \\
\text { pattern }\end{array}$ & $\begin{array}{l}\text { Additional pathologic } \\
\text { characteristics }\end{array}$ & $\begin{array}{l}\text { Follow-up } \\
\text { range }\end{array}$ & $\begin{array}{l}\text { Recurrence } \\
\text { (n } \\
\text { /available } \\
\text { follow-up) }\end{array}$ & Ref \\
\hline $\begin{array}{l}\text { Shimada M } \\
\text { et al. (2001) }\end{array}$ & 40 & $\begin{array}{l}\text { Partial } \\
\text { hepatectomy }\end{array}$ & NA & $\begin{array}{l}80 \\
\text { (median) }\end{array}$ & $\begin{array}{l}\text { Cirrhosis in } \\
(24 / 40) \mathrm{d} / \mathrm{t} \mathrm{HCV} \\
(62.2 \%), \mathrm{HBV} \\
(30 \%) \text { or } \\
\text { diabetes }(20 \%)\end{array}$ & NA & $\begin{array}{l}\text { G1-G2 }(25 / 40) \text {; tumor } \\
\text { cell infiltration in the } \\
\text { portal vein }(45 \%) \text {; tumor } \\
\text { thrombus in the hepatic } \\
\text { vein }(12.5 \%) \text {; } \\
\text { intrahepatic metastasis } \\
(60 \%)\end{array}$ & $\begin{array}{l}\text { Up to } \\
\sim 14 \text { years }\end{array}$ & NA & [12] \\
\hline $\begin{array}{l}\text { Han YS et al. } \\
(2008)\end{array}$ & 1 & $\begin{array}{l}\text { Orthotopic } \\
\text { liver } \\
\text { transplant }\end{array}$ & $\begin{array}{l}\text { Poorly } \\
\text { defined low } \\
\text { attenuating } \\
\text { lesions }\end{array}$ & 327 & $\begin{array}{l}\text { Cirrhosis } d / t \\
\text { HBV }\end{array}$ & $\begin{array}{l}\text { Pseudoglandular } \\
\text { (per submitted } \\
\text { picture) }\end{array}$ & $\begin{array}{l}\text { Diffuse involvement; G1, } \\
\text { no microvascular or } \\
\text { macrovascular invasion }\end{array}$ & 18 months & None $(0 / 1)$ & [13] \\
\hline $\begin{array}{l}\text { Jakate S } \\
\text { et al. (2010) }\end{array}$ & 10 & $\begin{array}{l}\text { Orthotopic } \\
\text { liver } \\
\text { transplant }\end{array}$ & $\begin{array}{l}\text { No masses } \\
>1 \mathrm{~cm}\end{array}$ & Up to 252 & $\begin{array}{l}\text { Cirrhosis most } \\
\text { commonly } d / t \\
\mathrm{HCV} \text { and } \mathrm{ETOH} \text {; } \\
\text { some others } d / \mathrm{t} \\
\mathrm{HBV} \text { and } \mathrm{Al}\end{array}$ & $\begin{array}{l}\text { Pseudoglandular } \\
\text { and trabecular }\end{array}$ & $\begin{array}{l}\text { Diffuse involvement in } \\
80 \% \text { of cases }(8 / 10) ; \\
\text { predominantly } \mathrm{G} 1-\mathrm{G} 2 ; \\
\text { frequent small vessel } \\
\text { invasion noted }\end{array}$ & $>3$ years & 1 of 5 & [5] \\
\hline $\begin{array}{l}\text { Clayton EF } \\
\text { et al. (2015) }\end{array}$ & 26 & $\begin{array}{l}\text { Orthotopic } \\
\text { liver } \\
\text { transplant }\end{array}$ & $\begin{array}{l}\text { Known } \\
\text { tumor in } \\
73.1 \%\end{array}$ & $\begin{array}{l}51 \text { (median } \\
\text { peak) }\end{array}$ & $\begin{array}{l}\text { Cirrhosis most } \\
\text { commonly d/t } \\
\mathrm{HCV}(65.4 \%) \\
\text { and ETOH } \\
(7.7 \%) \text {; Al or } \\
\text { other }(11.5 \%)\end{array}$ & $\begin{array}{l}\text { Pseudoglandular, } \\
\text { trabecular and clear } \\
\text { cell }\end{array}$ & $\begin{array}{l}\text { Bi-lobar }(85 \% \text { of cases); } \\
\text { G1-G2 }(61.5 \%) ; \\
\text { microscopic vascular } \\
\text { invasion }(88.5 \%) ; \text { no } \\
\text { macrovascular invasion }\end{array}$ & $\begin{array}{l}\text { up to } \\
\sim 13 \text { years }\end{array}$ & $\begin{array}{l}56.7 \% \\
\text { overall } \\
\text { recurrence } \\
\text { rate at } \\
5 \text { years } \\
(\sim 15 / 26)\end{array}$ & [14] \\
\hline $\begin{array}{l}\text { Agni RM } \\
(2017)\end{array}$ & 1 & $\begin{array}{l}\text { Orthotopic } \\
\text { liver } \\
\text { transplant }\end{array}$ & $\begin{array}{l}3 \mathrm{~cm} \text { mass on } \\
\mathrm{MRI} \text { and } \mathrm{CT} ; \\
\text { also multiple } \\
\leq 1 \mathrm{~cm} \\
\text { ill-defined } \\
\text { nodules }\end{array}$ & Unknown & $\mathrm{HCV}$ & Pseudoglandular & $\begin{array}{l}\text { Innumerable lesions } \\
\text { throughout; G1-G2; no } \\
\text { vascular invasion }\end{array}$ & $\begin{array}{l}10 \text { months } \\
\text { (died of } \\
\text { disease) }\end{array}$ & NA & [15] \\
\hline $\begin{array}{l}\text { This } \\
\text { study (2019) }\end{array}$ & 5 & $\begin{array}{l}\text { Orthotopic } \\
\text { liver } \\
\text { transplant }\end{array}$ & $\begin{array}{l}\text { Known } \\
\text { tumor in one } \\
\text { case only }\end{array}$ & Up to 344 & $\begin{array}{l}\text { Cirrhosis } d / t \\
\text { HCV, ETOH, } \\
\text { NASH and HBV }\end{array}$ & $\begin{array}{l}\text { Pseudoglandular } \\
\text { and trabecular and } \\
\text { focal steatotic } \\
\text { pattern }\end{array}$ & $\begin{array}{l}\text { Predominantly G1-G2; } \\
\text { microscopic vascular } \\
\text { invasion in } 2 / 5 \text { cases; no } \\
\text { macrovascular invasion }\end{array}$ & $\begin{array}{l}\text { Up to } \\
3.25 \text { years }\end{array}$ & 2 of 5 & \\
\hline $\begin{array}{l}\text { Kwon R and } \\
\text { Oshima K } \\
(2019)\end{array}$ & 1 & $\begin{array}{l}\text { Orthotopic } \\
\text { liver } \\
\text { transplant }\end{array}$ & $\begin{array}{l}2.2 \mathrm{~cm} \text { inde- } \\
\text { terminate } \\
\text { nodule on } \\
\text { MRI }\end{array}$ & 160 & $\mathrm{ETOH}$ and $\mathrm{HCV}$ & $\begin{array}{l}\text { Pseudoglandular } \\
\text { and trabecular }\end{array}$ & $\begin{array}{l}\text { G2; }>95 \% \text { involvement } \\
\text { of parenchyma; } \\
\text { Microscopic vascular } \\
\text { invasion; no } \\
\text { macrovascular invasion }\end{array}$ & $\begin{array}{l}\text { At least } \\
18 \text { months }\end{array}$ & 1 of 1 & [16] \\
\hline
\end{tabular}

Patients described in several studies [5,13-15] and in a case from the Hans Popper Hepatopathology Society [16] are comparable with our cohort, since all of these patients underwent an orthotopic liver transplant (total hepatectomy) for cirrhosis. A literature review of CM-HCC clinicopathologic characteristics is summarized in Table 2. Summarized interpretation of cumulative data from literature review (Table 2) suggests that cirrhosis was due to various etiologies. Follow-up ranged from 10 months to more than 3 years, with recurrence for $50 \%$ (19 of 38) patients based on available follow-up data. Overall, the predominant pathologic growth pattern was pseudoglandular and trabecular. These tumors exhibited diffuse growth, had predominantly well-to-moderate differentiation, and some showed microscopic venous invasion. Supporting this notion that CM-HCCs behave as well-to-moderate differentiated tumors is our cohort's H\&E morphology, low MIB-1 proliferation index and negative AFP stain (MIB-1 and AFP stain done on a representative case only). However, this observation needs to be further supported by long-term follow-up data. Clayton et al. [14] looked at the histologic growth pattern and noted that patients with tumors in their 'clear cell' morphology with 'confined extent' category had a better prognosis compared with other subgroups. We observed that the predominant morphology was pseudoglandular. We did not attempt to designate clear cell morphology as a separate subgroup. According to the WHO Classification of Tumors, a high histologic grade is associated with a poor prognosis [3,6]. Consistent with this, our case 4 patient, who had poorly differentiated HCC in his dominant nodule, subsequently developed recurrence within a short time. 
Table 3. Immunohistochemical and special stain characteristics.

\begin{tabular}{|c|c|c|c|c|c|}
\hline Parameters & Case 1 & Case 2 & Case 3 & Case 4 & Case 5 \\
\hline Reticulin & $\begin{array}{l}\text { Thickened plates in } \\
\text { tumors }\end{array}$ & $\begin{array}{l}\text { Thickened plates in } \\
\text { tumors }\end{array}$ & $\begin{array}{l}\text { Thickened plates in } \\
\text { tumors }\end{array}$ & Not done & Not done \\
\hline Glypican-3 & (+) Patchy pattern & (+) Diffusely positive & (+) Diffusely positive & Not done & Not done \\
\hline CD34 & Not done & Sinusoidal pattern & Not done & Not done & Not done \\
\hline CK7 & Not done & $(-)$ & Not done & Not done & Not done \\
\hline CK19 & Not done & $(-)$ & Not done & Not done & Not done \\
\hline AFP & Not done & $(-)$ & Not done & Not done & Not done \\
\hline HepPar-1 & Not done & $\begin{array}{l}(+) \text { stains majority of } \\
\text { tumor }\end{array}$ & Not done & $\begin{array}{l}(+) \text { in well differentiated } \\
\text { to }(-) \text { in poor } \\
\text { differentiated }\end{array}$ & Not done \\
\hline MIB-1 & Not done & $\operatorname{Low}\left(15 \%^{\dagger}\right)$ & Not done & Not done & Not done \\
\hline
\end{tabular}

A limitation of this study is the short follow-up interval. This may be attributable to the fact that CM-HCC has received heightened academic interest among clinicians since the introduction of the Milan criteria in 1996, sparking debate about excess tumor burden and prognosis. The first pathologic case report of an orthotopic liver transplant for a patient with CM-HCC appeared in 2008 [13]. Surgeons at Johns Hopkins authored subsequent articles on CM-HCC in 2011 and 2012 [17,18]. Since this is a rare entity, we had only a small single-institution cohort, prohibiting performance of further statistical analyses. Another limitation of this study is that due to variation in reporting, variable time points in clinic visits (which add to the complexity in trending allograft function and immunosuppression regimen from available clinic notes and messages), it was very difficult to ascertain exact immunosuppression and treatment protocols. Given that this tumor is very rare, there is no established treatment protocol. Overall, in the postoperative period, all of our patients underwent surveillance with imaging, and treatments were also tailored to comorbidities (e.g., liver and kidney transplants, treatment for chronic hepatitis $\mathrm{B}$ and/or C, or targeted therapy for recurrence). We tried to assess peri-operative outcomes from clinical notes (reported allograft function, Karnofsky Scale and Eastern Cooperative Oncology Group Performance Scale).

\section{Conclusion}

CM-HCC evades clinical, radiologic and macroscopic detection. CM-HCC produces innumerable nodules that are frequently under the detection limits of modern multiplanar multisequence imaging limits of $2 \mathrm{~cm}$. Microscopic evaluation shows tumor burden in excess of pretransplant evaluation. At up to 3.25 years of follow-up, our cohort of CM-HCC had no recurrence in 60\% (3/5), solitary recurrence in 20\% (1/5) and died of disease in 20\% (1/5). Our cohort and those found in an exhaustive review of existing literature suggest that these tumors recurred at a frequency of $50 \%$ ( 19 of 38 patients). This may be due to an increased chance of diffuse tumor burden to have unsuspected microscopic venous invasion. Thus, it is reasonable to conclude that these patients should be cautiously followed by surveillance imaging protocol to monitor for recurrences.

\section{Future perspective}

Within the next 5-10 years, the question of whether these diffuse innumerable nodules are one or separate clones will be more clearly elucidated by molecular analysis. We predict that this may be the key to understanding the pathobiology of CM-HCC and developing targets for drug therapy. Also, we predict that there will be an increased recognition of CM-HCC as well as longer periods of imaging surveillance that will give us better insight on shortand long-term recurrence data.

\footnotetext{
Supplementary data

To view the supplementary data that accompany this paper please visit the journal website at: www.futuremedicine.com/doi/suppl/10.2217/hep-2020-0015
} 


\section{Author contributions}

M Xiong was the primary writer. C Patel was involved in funding acquisition as well as review and editing. U Manne was involved in review, editing and funding acquisition. S Al Diffalha was involved with conceptualization, funding acquisition, methodology and review and editing.

\section{Financial \& competing interests disclosure}

This study was supported, in part, by institutional funds awarded to C Patel, U Manne and S Al Diffalha. The authors have no other relevant affiliations or financial involvement with any organization or entity with a financial interest in or financial conflict with the subject matter or materials discussed in the manuscript apart from those disclosed.

No writing assistance was utilized in the production of this manuscript.

\section{Open access}

This work is licensed under the Attribution-NonCommercial-NoDerivatives 4.0 Unported License. To view a copy of this license, visit http://creativecommons.org/licenses/by-nc-nd/4.0/

\section{Summary points}

- Cirrhotomimetic Hepatocellular Carcinoma (CM-HCC) is a rare and recognized pattern exhibiting cirrhosis-like growth with a reputation for evading pretransplant clinical and radiographic detection.

- Background liver cirrhosis was due to various etiologies including nonalcoholic steatohepatitis, hepatitis C virus, hepatitis $B$ virus and alcohol hepatitis.

- CM-HCC produces innumerable nodules diffusely throughout the liver, which are often small and sub-centimeter.

- Therefore, these tumors evade detection with multiplanar multisequence MRI which have poor sensitivity and specificity for tumors $\leq 2 \mathrm{~cm}$.

- Pretransplant serum AFP is not infrequently normal or minimally elevated.

- Tumors exhibit predominantly trabecular and pseudoglandular growth patterns and well-to-moderate histologic differentiation.

- Poor histologic grade and lymphovascular invasion may predict aggressive tumor behavior.

- Glypican-3 expression and Reticulin special stain (showing thickened plates in tumor) aid in confirming HCC.

- Literature review of $\mathrm{CM}-\mathrm{HCC}$ showed recurrence rate of $50 \%$, so we believe these patients should be cautiously followed by a surveillance protocol.

\section{References}

Papers of special note have been highlighted as: $\bullet$ of interest; $\bullet \bullet$ of considerable interest

1. American Cancer Society. Cancer facts \& figures 2019. (2019).

https://www.cancer.org/research/cancer-facts-statistics/all-cancer-facts-figures/cancer-facts-figures-2019.html

2. Bruiz J, Sherman M. AASLD practice guideline. Management of hepatocellular carcinoma. Hepatology 42, 1208-1236 (2005).

3. Digestive System Tumours, WHO Classification of Tumours, 5th edition, volume 1. WHO Classification of Tumours Editorial Board. IARC 229-239 (2019).

4. Marrero JA, Kulik LM, Sirlin CB et al. Diagnosis, staging, and management of hepatocellular carcinoma: 2018 practice guidance by the American association for the study of liver diseases. Hepatology 68(2), 723-750 (2018).

5. Jakate S, Yabes A, Giusto D et al. Diffuse cirrhosis-like hepatocellular carcinoma: a clinically and radiographically undetected variant mimicking cirrhosis. Am. J. Surg. Pathol. 34(7), 935-941 (2010).

-• A great article which defines cirrhotomimetic hepatocellular carcinoma (CM-HCC).

6. Han DH, Choi GH, Kim KS et al. Prognostic significance of the worst grade in hepatocellular carcinoma with heterogeneous histologic grades of differentitation. J. Gastroenterol. Hepatol. 28(8), 1384-1390 (2013).

7. Addley HC, Griffin N, Shaw AS et al. Accuracy of hepatocellular carcinoma detection on multidetector CT in a transplant liver population with explant liver correlation. Clin. Radiol. 66(4), 349-356 (2011).

- This is an imaging-pathologic correlation article that discusses HCC detection in patients with cirrhosis undergoing evaluation for liver transplant that compares newer multidetector computed tomography (CT) imaging modality to prior helical CT, and explant liver correlation.

8. Mazzaferro V, Regalia E, Doci R et al. Liver transplantation for the treatment of small hepatocellular carcinomas in patients with cirrhosis. N. Engl. J. Med. 334, 693-699 (1996).

-. Outlines liver transplantation criteria. 
9. Pavel MC, Fuster J. Expansion of the hepatocellular carcinoma Milan criteria in liver transplantation: future directions. World J. Gastroenterol. 24(32), 3626-3636 (2018).

- Outlines liver transplantation criteria and thoughts.

10. Eggel H. Über das primäre Carcinom der Leber. Beitr. Pathol. Anat. Allerg. Pathol. 30, 506-604 (1901).

11. Yuki K, Hirohashi S, Sakamoto M et al. Growth and spread of hepatocellular carcinoma. A review of 240 consecutive autopsy cases. Cancer 66(10), 2174-2179 (1990).

12. Shimada M, Rikimaru T, Hamatsu T et al. The role of macroscopic classification in nodular-type hepatocellular carcinoma. Am. J. Surg. 182(2), 177-182 (2001).

13. Han YS, Choi DL, Park JB. Cirrhotomimetic type hepatocellular carcinoma diagnosed after liver transplantation - eighteen months of follow-up: a case report. Transplant. Proc. 40(8), 2835-2836 (2008).

14. Clayton EF, Malik S, Bonnel A et al. Liver transplantation and cirrhotomimetic hepatocellular carcinoma: classification and outcomes. Liver Transpl. 20(7), 765-774 (2014).

15. Agni RM. Diagnostic histopathology of hepatocellular carcinoma: a case-based review. Semin. Diagn. Pathol. 34(2), 126-137 (2017).

- This case-based review of HCC discusses a CM-HCC and current knowledge on clinical outcomes.

16. Hans Popper Hepatopathology Society. Interesting case July 2019. (2019). hanspopperhepatopathologysociety.org/2019/08/interesting-case-july-2019

- This case study is similar to ours and demonstrates that this is a recognized variant of hepatocellular carcinoma.

17. Demirjian A, Peng P, Geschwind J et al. Infiltrating hepatocellular carcinoma: seeing the tree through the forest. J. Gastrointest. Surg. 15(11), 2089-2097 (2011).

- Highlights surgeon's (clinical) perspective on CM-HCC.

18. Kneuertz PJ, Demirjian A, Firoozmand A et al. Diffuse infiltrative hepatocellular carcinoma: assessment of presentation, treatment, and outcomes. Ann. Surg. Oncol. 19(9), 2897-2907 (2012).

- This paper highlights surgeon's (clinical) perspective on CM-HCC. 